Junior Fellowships (£800 a year) : Dr. R. J. Shephard, changes in the dynamic pressure volumes and in the vital capacity of the lungs in man, with the view of elucidating various types of dyspncea (Department of Physiology, Guy's Hospital Medical School, London); Dr. J. R. Tata, normal and abnormal pathways of metabolism of the thyroid hormones (National Institute for Medical Research, Mill Hill) ; Dr. V. C. Abrahams, physiology and pharmacology of the hypothalamus, particularly in relation to the control of water balance (National Institute for Medical Research, Mill Hill); and T. F. Slater, enzymic constitution of the mammary gland in relation to lactation and, in particular, the synthesis of milk proteins (Department of Biochemistry, University College, London).

\section{Institution of Mining and Metallurgy: Awards}

THe Council of the Institution of Mining and Metallurgy has made the following awards: Gold Medal of the Institution, Dr. J. A. Bancroft, in recognition of his long and distinguished services to the mineral industry in southern Africa and in the advancement of the science and practice of economic geology; Honorary Membership of the Institution, the Hon. C. A. Banks, in recognition of his services to the mining industry, with particular reference to his pioneering work in the introduction of air transport for the equipment of poorly accessible mineral properties; the Right Hon. Viscount Chandos, for his services to metallurgical industries in the United Kingdom; and Mr. G. F. Layeock, past-president of the Institution, for his services to the mineral industry and to the Institution; Consolidated Gold Fields of South Africa, Limited, Gold Medal for the session 1954-55, Mr. J. F. G. R. Heywood, for his paper entitled "Pressure Manifestations at Great Mining Depths on the Witwatersrand" (Trans. Inst. Min. Metall., 64); and The Consolidated Gold Fields of South Africa, Limited, Premium of Forty Guineas for 195455 , Dr. J. J. Brummer, for his paper entitled "The Geology of the Roan Antelope Orebody" (Trans. Inst. Min. Metall., 64) ; William Frecheville Student's Prize for the-session 1954-55, Mr. F. M. Vokes and Mr. W. G. Jeffery conjointly for their paper entitled "The Geology of New Consols Mine, Cornwall" (Trans. Inst. Min. Metall., 64).

\section{Avogadro Centenary Commemoration in Rome}

This year is the centenary of the death of Amedeo Avogadro, the Italian chemist and physicist whose discovery of one of the fundamental laws concerning the behaviour of gases brought him universal fame. To mark the occasion, the Accademia Nazionale dei $\mathrm{XL}$, of which Amedeo Avogadro was a member, is organizing a commemoration ceremony which will take place on June 6 in Rome at the Capitol in the presence of representatives of the Italian Government and of foreign countries and prominent personalities from Italian cultural life. Appreciations of Avogadro's work will be given by Prof. Francesco Severi, president of the Accademia dei XL, Sir Cyril Hinshelwood, of the University of Oxford, president of the Royal Society, Prof. Linus Pauling, of the Institute of T'echnology, Pasadena, and Prof. G. B. Bonino, of the University of Bologna.

\section{International Control of Pelagic Fisher:es}

Afrer discussion for several years, the International Law Commission last year agreed on rules to allow coastal States to prevent the fisheries near their own shores being exploited to the point of extermination by larger States. On May 2, The Times reported an attempt by representatives of Mexico and India to delete the provisions for compulsory arbitration included in the draft for the settlement of disputes. There are some resources such as oil, non-migratory fish, guano, weed and other marine products for which local jurisdiction seems reason. able. Others, such as whales, seals, salmon and other migratory fish, can be fished just as successfully in the deep ocean a thousand miles away. They are the same stocks as are fished at the coast and can be conserved only by international agreement. The work and success of the International Whaling Commission and the North Pacific Fur Seal Agreement are striking examples of how regulation and international co-operation can be achieved. It is clear from the report in The Times that the Law Com. mission and the General Assembly of the United Nations, while prepared to support well-founded claims, will not favour the general establishment of frontiers on the high seas. To the marine scientist such divisions of the ocean will be particularly objectionable. The usefulness of the seas and oceans to the small States as well as to the principal maritime powers depends ultimately on international cooperation in their study and use. The international councils, unions, and United Nations organizations will do more to improve the fisheries than is likely to be achieved by imposing too many local restrictions. There would soon be no whales off any coast in the southern hemisphere if it were not for active international co-operation in the Antarctic. 'The same co-operative spirit will eventually be needed in other pelagic fisheries.

\section{Colonial Advisory Council of Agriculture, An:mal Health and Forestry}

THE Secretary of State for the Colonies, Mr. Alan Lennox-Boyd, has amended the terms of reference of the Colonial Advisory Council of Agriculture, Animal Health and Forestry which was first set up in 1929, and its membership has been altered to bring it in line with its new functions. The new terms of reference are as follows: (1) to keep under review the general conditions of agriculture, animal health and forestry in the Colonial Empire and to maintain contact with the work of the Colonial Governments in these spheres of development ; (2) to advise the Secretary of State or individual Colonial Governments at their request upon general policy and development or particular aspects of policy and development in the fields of agriculture, animal health and forestry; (3) to bring to the attention of the Committee for Colonial Agriculture, Animal Health and Forestry Research in broad outline such problems in these fields on which research or investigation is required; (4) at the request of Colonial governments to visit or make arrangements for visits by other than members of the Council.

The membership of the Council is as follows: Lord Lloyd, Parliamentary Under-Secretary of State for the Colonies (chairman); Mr. W. B. L. Monson, Assistant Under-Secretary of State, Colonial Office (vice-chairman); Prof. W. I. B. Beveridge, professor of animal pathology, University of Cambridge; $\mathrm{Mr}$. W. H. Cashmore, director of the National Institute of Agricultural Engineering; Mr. C. Clark, director of the Institute for Research in Agricultural Economics, University of Oxford ; Sir Geoffrey Clay, agricultural adviser to the Secretary of State for the 